\title{
PENINGKATAN KETERAMPILAN BAHASA INGGRIS MASYARAKAT PEGUNUNGAN DI DESA BETAO KABUPATEN SIDRAP
}

\author{
Andi Febriana Tamrin, Yanti \\ Universitas Fajar, Makassar, Indonesia \\ andifebriana90@unifa.ac.id
}

\begin{abstract}
Abstrak: Pentingnya softskill bagi generasi muda menjadi dasar atas penyusunan Program Kemitraan Masyarakat (PKM) ini. Fokus dari kegiatan pengabdian ini adalah peningkatan minat belajar bahasa inggris masyarakat pegunungan berbasis buku cerita rakyat lingkungan/alam sekitar serta peningkatan softskill mitra Karang Taruna Desa Betao Kecamatan Pituriawa Kabupaten Sidrap. Tujuan khusus dalam PKM ini adalah dalam rangka untuk peningkatan minat belajar serta peningkatan ketrampilan Bahasa Inggris (soft skill). Beberapa metode yang digunakan dalam Program Kemitraan Masyarakat (PKM) ini adalah metode tanya jawab dan diskusi untuk mengidentifikasi pengetahuan dan teknologi pendukungnya. Metode ceramah digunakan pada saat proses belajar dan pemahaman teoritis bahasa inggris. Hasil pengabdian masyarakat yang telah dilatih menunjukkan bahwa pembelajaran Bahasa Inggris berbasis buku cerita bertema alam lebih mudah di mengerti oleh siswa yang diajar. Dengan menggunakan metode ini, terjadi peningkatan yang cukup baik bagi peserta didik. Selain itu, hasil lain yang diperoleh adalah para pemuda dan anak-anak lebih cepat menyerap materi pembelajaran Bahasa Inggris dan kegiatan ini juga menjadi awal untuk kegiatan lainnya.
\end{abstract}

Kata Kunci: Bahasa Inggris; buku bergambar; soft skill

\begin{abstract}
The importance of soft skills for the young generation is the rationale for this community service program. The focus of the present program is to increase the interest of learning English for highlanders based on environmental/natural folklore books and soft skill enhancement for Karang Taruna in Betao Village, Pituriawa District, Sidrap. The specific purpose is to enhance learning interest and improve English (soft skills). The methods used in the program are the question and answer and discussion to identify knowledge and supporting technology. The lecturing method was used during the learning process and theoretical understanding of English. The results showed that English learning based on natural-themed storybooks is easier for students to understand. Using the book, the students have considerable improvement. In addition, another result was that young people and children could rapidly learn English and become the beginning of other activities.
\end{abstract}

Keywords: English; picture book; soft skill

\section{Pendahuluan}

Pendidikan merupakan salah satu kebutuhan yang mendasar bagi manusia. Ada banyak pelajaran yang diajarkan kepada masyarakat Indonesia dari Pendidikan dasar sampai dengan di tingkat perguruan tinggi. Meskipun demikian, dalam proses belajar itu sendiri terkadang terdapat kelemahan. Hal ini dapat terlihat dari sarana dan prasarana yang ada di daerah-daerah yang keberadaanya cukup jauh dari ibukota. Sarana dan prasarana yang didapatkan oleh para siswa di daerah berbeda dengan sarana dan prasarana yang didapatkan oleh siswa di kota besar. Akibatnya, pengetahuan anak-anak yang memiliki latar belakang pendidikan di perkotaan biasanya terdapat kesenjangan dengan anak-anak yang berada di daerah. Kesenjangan ini akan semakin nampak jelas ketika mereka masuk di jenjang perguruan tinggi. 
Perlu disadari bahwa teknologi saat ini berkembang dengan sangat pesat. Perkembangan teknologi turut mempengaruhi beberapa hal. Salah satunya yang paling terpengaruh adalah pendidikan. Pentingnya mempelajari bahasa asing juga telah disampaikan oleh salah satu filsuf dunia yang berasal dari Jerman, Johann Wolfgang von yang menyatakan, "Those who know nothing about foreign language, they know nothing about their own"(Handayani, 2016). Hal yang tersirat dari perkataan oleh Wolfgang diatas dapat diinterpretasikan sebagai pentingnya mempelajari bahasa lain (asing) selain bahasa ibu. Mengacu pada hal ini, dan melihat kondisi perkembangan teknologi dibutuhkan juga penguasaan bahasa asing. Salah satu bahasa asing yang paling penting di dunia adalah Bahasa Inggris. Bahasa ini merupakan lingua franca, bahasa yang dunia yang memiliki penutur terbanyak. Dengan demikian jika memiliki kemampuan berbahasa inggris maka akan meningkatkan peluang di masa depan untuk bersaing mendapatkan hidup yang lebih baik.

Pada dasarnya, pembelajaran bahasa itu terkait dengan pelajaran komunikasi. Pelajaran komunikasi ini kemudian dikaitkan dengan pelajaran lisan ataupun tulisan di dalam dunia pendidikan. Sebagai sarana komunikasi, bahasa memiliki beberapa fungsi yang kemudian diperlihatkan dalam beberapa konteks yang bermakna. Target utama dalam komunikasi lisan ini sendiri yaitu agar lawan bicara mampu memahami budaya dari penutur (Husein \& Dewi, 2019).

Perkembangan teknologi dan pengaruhnya yang pesat dalam berbagai bidang kehidupan. Oleh karena itu pengetahuan tidak hanya diberikan di bangku sekolah namun juga harus diberikan di lingkungan masyarakat di daerah yang belum memadahi pendidikannya. Manfaat dan kebergunaan pengetahuan terutama pada bidang pengetahuan Bahasa Inggris tak dapat dipungkiri telah mengubah cara kerja berbagai kegiatan di hampir semua bidang kehidupan. Salah satu tolok ukur kebergunaan Bahasa Inggris dalam kehidupan sehari-hari dapat dilihat dari berkembangnya bidang pariwisata yang makin diminati oleh wisatawan dari luar negeri. Perkembangan teknologi yang begitu pesat saat ini sangat berdampak pada kerusakan lingkungan yang terjadi di planet bumi. Penemuan-penemuan yang diciptakan oleh manusia memiliki tujuan yang cenderung membuat hidup mereka lebih mudah. Akan tetapi, bahan-bahan yang mereka gunakan untuk penemuan ini berasal dari alam seperti pohon, batu, dan air. Sebagai hasil dari penggunaan bahan mentah ini menimbulkan polusi yang membahayakan atmosfer bumi. Ini berarti semakin berkembang inovasi manusia, semakin bahaya lingkungan kita.

Sebagai salah satu mata pelajaran yang wajib, Bahasa Inggris telah diperkenalkan kepada anak-anak sedini mungkin. Akan tetapi metode pengajaran yang berbeda menjadi salah satu kekurangan yang membuat mata pelajaran ini kurang digemari. Salah satu cara untuk mengatasi hal ini adalah dengan mengembangkan metode belajar melalui perpaduan pengajaran dalam dan di luar kelas. Sebagai contoh metode ini adalah dengan melakukan proses belajar di alam bebas, misalnya di lapangan atau di sawah.

Telah banyak metode yang digunakan untuk memperkaya gaya belajar untuk Bahasa Inggris. Salah satunya itu menerapkan konsep English Day. Dalam hal ini diterapkan waktu khusus untuk berbahasa Inggris bagi para partisipan. Penyelenggaraan English Day ini menjadi wadah yang bermanfaat bagi para guru dan karyawan yang berada di SMA Islam Terpadu Pekanbaru. Kegiatan ini berlangsung selama kurang lebih satu bulan. Hasil dari kegiatan 
pengabdian ini dapat meningkatkan minat belajar peserta dengan menggunakan konsep English Day (Syahfutra \& Niah, 2017).

Selanjutnya, salah satu metode lainnya yaitu meningkatkan kemampuan membaca dengan dua metode berbeda yaitu Intensive Reading (IR) dan Extensive Reading (ER). IR dapat diartikan sebagai metode membaca dengan mempertimbangkan keinginan pembacanya. Jadi ketika mereka diberikan teks bacaan, harus sesuai dengan minat dan keinginan pembacanya. Sedangkan $E R$ didefenisikan sebagai metode membaca yang memberikan perhatian kepada kemampuan pembaca. Kemampuan mengacu kepada kemampuan berbahasa dan materi yang diberikan harus materi bertingkat yang sesuai mengikuti perkembangan kebahasaan mereka. Beberapa penelitian terdahulu seperti Muchtar dan Ali (2017) menerapkan dua metode untuk meningkatkan kemampuan baca mahasiswa. Dua metode yang digunakan adalah $I R$ dan $E R$. Penelitian ini bertujuan untuk meningkatkan kreativitas belajar mahasiswa dan menjadi tambahan referensi mengajar Bahasa Inggris terutama dalam hal Reading (Membaca) bagi para dosen (Muchtar \& Ali, 2017).

Dalam proses belajar, media merupakan salah satu hal yang sangat mempengaruhi gaya belajar siswa. Salah satu media yang digunakan dalam proses belajar Bahasa Inggris adalah internet. Menggunakan internet sebagai media telah dilakukan oleh beberapa pihak, salah satu yang telah melakukannya adalah Sunardi (2011). Dalam makalahnya, internet digunakan sebagai media pembelajaran Bahasa Inggris karena dianggap internet mampu membuat pembelajar mempraktekkan komunikasi secara nyata (Sunardi, 2011). Hal ini sejalan dengan pendapat yang mengatakan bahwa komputer juga dapat membantu proses belajar Bahasa Inggris. Meylina telah melaksanakan kegiatan ini. Menurut hasil dari kegiatan yang telah dilakukannya, metode seperti ini juga cukup efektif bagi siswa untuk mengatasi kejenuhan dalam belajar (Meylina \& Sammir, 2019).

Desa Betao dipilih menjadi tempat kegiatan pengabdian karena menurut pengamatan yang dilakukan, metode pengajar yang dilaksanakan di sekolah masih menggunakan metode tradisonal. Begitupun dengan pelajaran Bahasa Inggris ditingkat sekolah dasar. Pengajaran yang senantiasa dilakukan di dalam kelas kerapkali membuat mereka bosan dan jenuh. Setelah melalui pengamatan, kondisi alam yang cukup indah dapat menjadi penunjang untuk proses belajar yang dapat memberi kesan positif dan menyegarkan bagi siswa. Berdasarkan pertimbangan tersebut, maka tim memutuskan untuk memilih lokasi ini.

Pembelajaran Bahasa Inggris bagi anak-anak sekolah dasar berbasis lingkungan saat ini belum sepenuhnya dianggap penting oleh pemerintah. Padahal jika ditelusuri lebih mendalam lagi, metode pembelajaran akan sangat membantu siswa dalam meningkatkan kesadaran akan pentingnya menjaga lingkungan sedini mungkin. Penting bagi manusia untuk menyadari bahwa dengan berkembangnya zaman, maka kemampuan manusia pun dituntuk untuk mengikutinya. Tapi, pencegahan akan hal yang membahayakan juga penting untuk selalu diingat.

Metode pembelajaran ini juga akan meningkatkan kemampuan bahasa anak-anak yang akan sangat berguna bagi kehidupan mereka di masa depan nantinya. Sayangnya hal ini sepertinya terkendala dengan banyaknya asumsi dalam masyarakat yang beranggapan bahwa menguasai bahasa Inggris akan membuat mereka lupa budaya dan bahasa lokal mereka. Jika 
hal ini yang terus menjadi pegangan akan penting atau tidaknya Bahasa Inggris bagi anakanak, maka kesadaran mereka akan lingkungan akan semakin berkurang. Tentunya secara otomatis juga soft skill yang seharusnya membantu mereka di kemudian hari tidak akan terwujud.

Salah satu upaya untuk membuat anak-anak lebih bergairah belajar Bahasa Inggris adalah dengan mendatangi Karang Taruna di desa ini. Karang taruna merupakan tempat atau wadah yang menampung masyarakat khususnya generasi muda di suatu daerah. Organisasi ini dibentuk langsung oleh masyarakat dengan tujuan untuk membina dan mengembangkan sumberdaya manusia dan kegiatan ekonomi produktif yang menggunakan sumberdaya alam di daerah tersebut. Setelah itu, sekolah dasar juga merupakan salah satu tempat untuk memulai pengajaran berbasis ini. Oleh karena itu, kegiatan pengabdian ini memiliki dua wadah untuk mengembangkan metode pembelajaran Bahasa Inggris untuk meningkatkan minat dan softskil masyarakat Desa Betao.

Metode dan pendekatan kepada alam dalam pembelajaran Bahasa Inggris dalam penerapannya tidak akan memberikan banyak tantangan bagi anak-anak. Tujuan utama pembelajaran ini adalah untuk mendekatkan dan meningkatkan kesadaran anak-anak akan pentingnya menjaga alam sebagai tempat tinggal mereka saat ini dan di masa depan. LensikOberstein pernah mengatakan bahwa, "the bond between children and the environment arises generally because John Locke believes in the existence of "true nature" in children" (Tamrin \& Magfirah, 2019). Ini memiliki makna bahwa sesungguhnya ikatan batin antara anak-anak dan lingkungan itu ada. Hal ini dikarenakan dalam diri anak-anak itu sendiri merupakan suatu yang nyata dan murni, dan sejatinya sifat inilah yang sangat cocok dalam mengembangan metode belajar Bahasa Inggris seperti ini (Tamrin \& Magfirah, 2019).

Berdasarkan uraian yang telah di tuliskan di atas maka kegiatan pengabdian ini berfokus pada peningkatan ketrampilan Bahasa Inggris di desa mitra. Program pengabdian ini mengarah kepada bentuk pelatihan untuk memperkaya kosa kata ( vocabulary) dan percakapan sehari-hari (daily conversation). Pengajaran mengenai daily conversation dipilih dengan alasan bahwa hal inilah yang dibutuhkan oleh pemuda karang taruna. Hal ini dikarenakan tim pengabdi berharap bahwa kedepannya mereka dapat memanfaatkan skill ini nantinya dalam dunia kerja (Wulandari, 2018). Target luaran yang ingin dicapai dari kegiatan ini adalah publikasi di jurnal ilmiah, publikasi pada media elektronik dan pendokumentasian kegiatan berupa video.

\section{Metode}

Dalam kegiatan ini digunakan pendekatan service learning. Pedekatan ini merupakan salah santu dari bentuk implementasi yang dicetuskan oleh John Dewey (St. Syamsudduha \& Tekeng, 2017). Menurutnya, pendekatan seperti ini dapat terjadi proses pembelajaran jika peserta didik secara aktif mengkonstruksi makna melalui pengalaman nyata yang terbimbing. Melalui proses ini mereka nantinya dapat mengembangkan kompetensi mereka dengan berfikir kritis melalui refleksi. Di saat yang sama pula, mereka dapat berkontribusi kepada masyarakat sebagai perwujudan tugas kemasyarakatan mereka (St. Syamsudduha \& Tekeng, 2017). 
Kegiatan pengabdian masyarakat ini dibuat dalam beberapa tahapan yang telah dirancang dengan baik. Tujuannya agar program ini diharapkan mampu berjalan sesuai dengan yang diharapkan. Tahapannya adalah sosialisasi, pelatihan, pendampingan dan evaluasi (Susanti \& Rukiati, 2017). Tahapan ini dipilih karena berdasarkan hasil pengamatan yang dilakukan, tahapan inilah yang seyogyanya paling cocok untuk diterapkan.

Metode pelaksanaan dalam kegiatan pengabdian ini berkisar pada kegiatan pelatihan Bahasa Inggris. Untuk melaksanakan kegiatan pelatihan ini dilaksanakan dengan beberapa cara. Metode ini dipilih karena dianggap cocok dalam pelaksanaan kegiatan ini. Metode-metode tersebut ialah: (a) Tanya jawab dan diskusi; Metode tanya jawab digunakan untuk membantu menstimulasi peserta untuk berfikir lebih kritis dan metode diskusi digunakan agar memperluas wawasan peserta mengenai topik belajar. Salah topik yang didiskusikan adalah wawasan umum peserta mengenai cerita rakyat yang ada pada lingkungan sekitar. (b) Ceramah dan diskusi; Metode ini digunakan pada saat penyajian materi-materi yang berbentuk pengetahuan dan pemahaman teoritis bahasa inggris. (c) Demonstrasi; Metode ini digunakan untuk memberikan dan mempraktekkan cara berbahasa inggris dengan menerjemahkan cerita rakyat lingkungan/alam sekitar. (d) Simulasi: metode ini digunakan untuk memperlihatkan hasil dari suatu media buku cerita dan keberhasilan bahasa inggris yang telah diimplementasikan.

Kegiatan ini dilaksanakan dengan menjadikan siswa sekolah dasar dan pemuda karang taruna sebagai mitra. Kegiatan ini dilakukan selama kurang lebih 8 bulan. Tahapan pelaksanaan kegiatan ini adalah tahap persiapan, pre-test (khusus untuk mitra Karang taruna), pelatihan, evaluasi dan monev, post-test, dan penyusunan luaran kegiatan Dalam tiap pertemuan diasampaikan materi yang terkait dengan peningkatan keterampilan berbahasa inggris bagi mitra.

Skema dari proses kegiatan pengabdian kepada masyarakat ini dapat terlihat dari bagan alir dibawah ini:

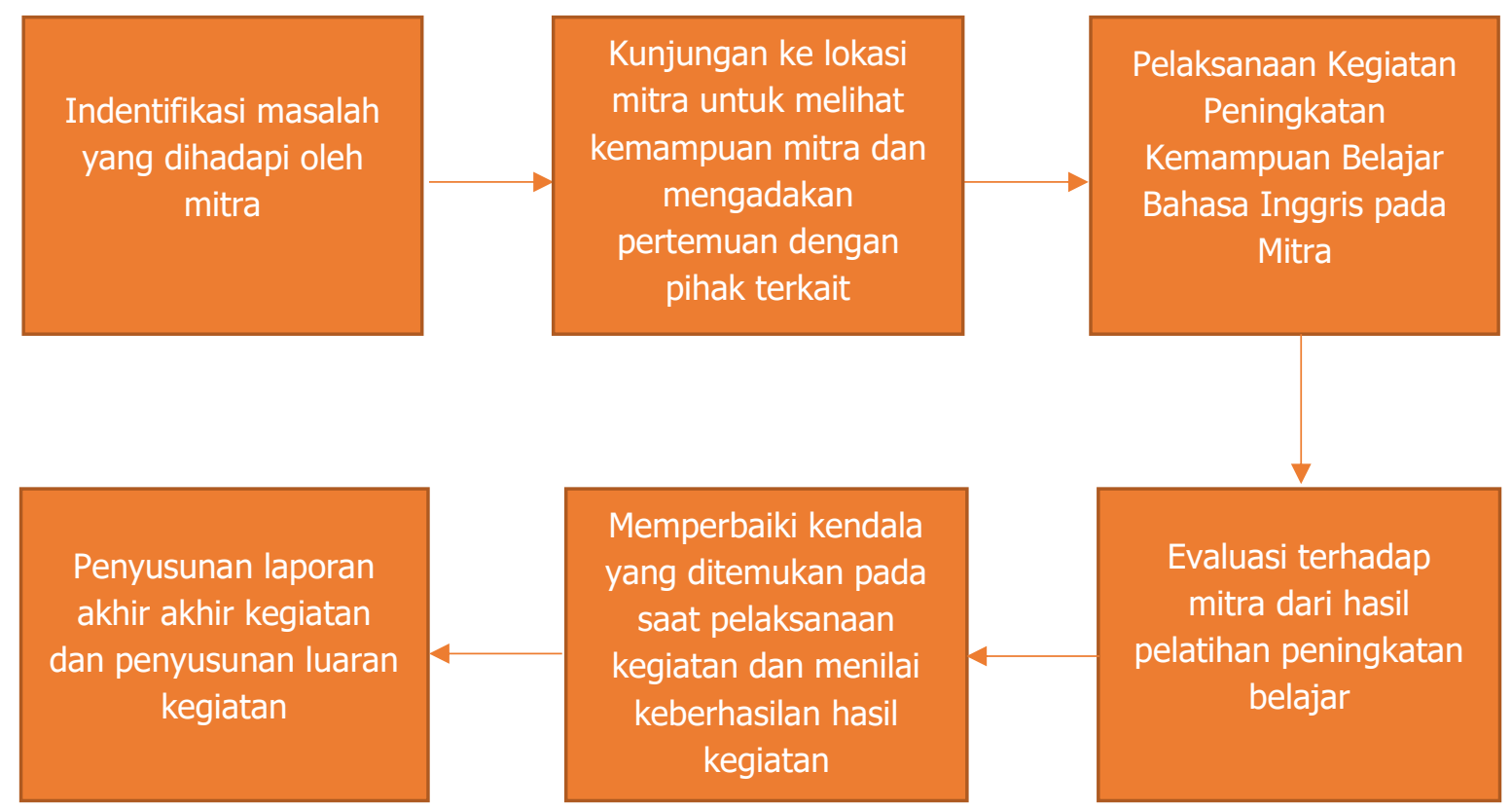

Bagan 1. Diagram Alur Pelaksanaan Kegiatan 


\section{Hasil dan Pembahasan}

Kegiatan pengabdian kepada masyarakat ini memfokuskan untuk melatih kemampuan (softskill) mitra, yaitu siswa sekolah dasar dan pemuda karang taruna. Permasalahan yang terlebih dahulu diselesaikan adalah mengajarkan Bahasa Inggris dasar bagi siswa sekolah dasar kemudian dilanjutkan dengan memberikan materi kepada pemuda karang taruna. Cara yang dipilih untuk menerapkan pelatihan dilandasi oleh pemikirian Van Els yang menyatakan bahwa guru yang baik adalah guru yang mampu mengaplikasikan ilmunya secara langsung di bidang kebahasaan (Dahniar, Nurmaya, \& Irsan, 2018).

Mengacu pada hasil identifikasi masalah yang dihadapi oleh mitra, maka tim pengabdi dapat memberikan solusi kepada mitra sebagai berikut:

a. Menyiapkan sumber daya untuk melakukan kegiatan pengabdian. Sumber daya yang disiapkan adalah dosen dan mahasiswa dari program studi terkait. Pemilihan tim pengabdi tentunya disesuaikan oleh kemampuan yang dimiliki oleh masing-masing pengajar. Bagi mitra, solusi yang ditawarkan berupa adanya sumber daya bisa membuat mitra mendapatkan sudut pandang baru baru dalam pengajaran. Selain itu, mitra dan pengabdi dapat bertukar ilmu dan pengetahuan dalam proses kegiatan ini nantinya. Sehingga, kedua pihak dapat mendapatkan manfaat dari kegiatan ini.

b. Selain melakukan kegiatan peningkatan kemampuan Bahasa Inggris kepada mitra, tim pengabdi juga tidak lupa untuk mensosialisasikan dan memperkenalkan nilai-nilai kewirausahaan uang merupakan ciri khas dari Universitas Fajar.

Pelaksanaan kegiatan yang berlangsung selama beberapa minggu berjalan dengan lancar. Pada kegiatan awal, sasaran awal adalah siswa sekolah dasar. Fokusnya adalah pengajaran Bahasa Inggris berbasis alam dengan menggunakan buku cerita bergambar. Antusiasme yang ditunjukkan oleh para siswa terlihat sangat baik. Mereka terlihat sangat bersemangat ketika melihat tim pengabdi bersama rombongan membawa buku bergambar yang akan digunakan.

Siswa sekolah dasar dipilih menjadi yang pertama karena menurut tim, waktu dan tempat mereka lebih fleksibel. Tentunya yang tim pengabdi lakukan pertama kali adalah menentukan kelas yang akan digunakan. Kelas yang dipilh untuk pertama kalinya adalah siswa yang duduk di kelas empat, kemudian kelas lima dan terakhir kelas enam. Ketiga kelas ini dijadikan sebagai objek karena siswa di kelas ini dianggap cukup dewasa dan telah mempelajari Bahasa Inggris. Oleh karena itu, mereka dapat menyerap lebih cepat dibandingkan dengan kelas lainnya.

Kegiatan pertama dimulai dengan memperkenalkan kosa kata dasar dan pembagian kelas kata. Dalam kegiatan ini tim menggunakan media berupa powerpointyang didalamnya terdapat gambar yang mewakili part of speech. Pengenalan kelas kata dimulai dengan kelas kata benda (noun), kata kerja (verb), kata sifat (adjective), kata keterangan (adverb), kata sambung (conjunction), kata depan (preposition), kata ganti (pronoun) dan kata seru (interjection). Tim memilih kata-kata yang mewakili tentunya dengan tema yang terkait dengan alam. Misalnya, untuk kata benda, dipilih kata pohon (tree). Selanjutnya untuk kata ganti (pronoun), maka dipilih kata saya (I). Untuk verb, dipilih kata menanam (plant). Pada kata keterangan, dipilih 
kata halaman (yard). Kesemua kata ini kemudian dirangkaikan menjadi sebuah kalimat yang menjadi, "I plant a tree in my yard". Kalimat ini menunjukkan bahwa anak-anak diajarkan untuk mempelajari kata-kata sederhana yang kemudian dirangkai dalam kalimat yang tentunya terkait dengan metode belajar yang menggunakan alam sebagai acuan.

Selanjutnya, proses pembelajaran diterapkan dengan memberikan buku bergambar ataupun gambar-gambar yang anak-anak dapat nikmati melalui laptop. Sesi ini dilakukan dengan memperkenalkan kepada anak-anak mengenai kosakata dasar (vocabulary) yang bertemakan alam. Langkah yang dilakukan pertama adalah, menunjukkan ilustrasi cerita kepada siswa yang terdapat pada laptop. Setelah itu, tim kemudian menuntun siswa untuk menyebutkan hal yang mereka lihat di buku bergambar. Jika siswa kesulitan, maka tim kemudian membantu untuk mengarahkan mereka menyebutkan apa yang mereka lihat. Bendabenda yang mereka lihat adalah segala benda yang memiliki kaitan dengan kebersihan lingkungan.
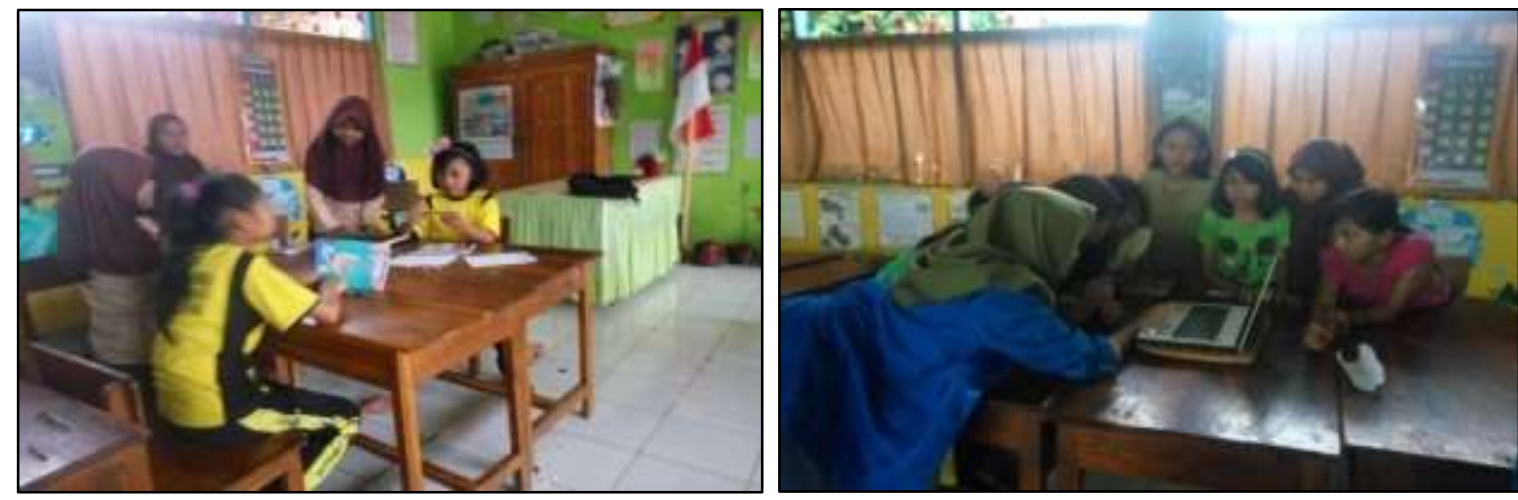

Gambar 1. Situasi Belajar

Setelah kegiatan itu, para siswa diajak untuk melakukan tur sekolah. Kegiatan ini dilakukan menjelang akhir pelatihan. Agenda yang terdapat dikegiatan ini adalah kegiatan dimana para siswa melakukan permainan. Salah satu permainan yang dilakukan adalah permainan tebak tumbuhan. Permainan ini dimulai dengan satu orang siswa yang berusaha untuk menebak tumbuhan yang ditunjuk oleh pelatih. Tumbuhan yang ditunjuk itu kemudian siswa akan berusaha untuk menebak nama tumbuhan tersebut. Tentunya tebak nama ini dilakukan dalam Bahasa Inggris. Selain menebak gambar, pelatih juga menjelaskan fungsi dari tumbuhan tersebut dan alasan mengapa tumbuhan perlu dilestarikan.

Penjelasan mengenai fungsi juga ditunjukkan dengan memperlihatkan gambar dari tanaman tersebut. Gambar tersebut menunjukkan kata yang mewakili fungsi tanaman. Contohnya, mangga (Manggo), siswa dapat melihat gambar buah mangga dan gambar anak lelaki dan tulisan vitamin $C$ for your immunity. Selain itu, gambar hasil olahan buah mangga juga diperlihatkan seperti gambar jus dan kue. Dengan memperlihatkan dan menjelaskan seperti ini siswa terlihat sangat bersemangat dalam belajar dan kejenuhan mereka dapat diatasi.

Metode ini telah diterapkan sebelumnya, metode mengajar anak-anak untuk membuat mereka mengerti Bahasa Inggris dengan cara yang lebih komprehensif adalah dengan membuat mereka menyadari lingkungannya. Dengan demikian, metode ini memberikan dua keuntungan. 
Pertama adalah dalam pembelajaran Bahasa Inggris, kedua adalah membuat mereka akrab dengan lingkungannya (Tamrin \& Magfirah, 2019). Selain itu, mereka juga tidak akan mudah merasa jenuh dengan menggunakan metode seperti ini.

Selain itu, di kegiatan selanjutnya yang melibatkan karang taruna sebagai pesertanya, proses pembelajaran dilakukan sedikit berbeda dengan anak-anak. Dalam hal karang taruna, terlebih dahulu pemateri memberikan tes awal untuk melihat letak kemampuan mereka. Tes awal dalah hal ini hanya berupa tes percakapan biasa (daily conversation). Pelaksanaan tes ini berlangsung dengan baik karena setelah tes dapat terlihat kemampuan para pemuda di rasakan cukup untuk memulai pelajaran secara langsung.

Tes percakapan dipilih selain untuk melihat kemampuan secara langsung, tes ini juga dianggap sebagai cara untuk mengakrabkan diri dengan para pemuda. Tes percakapan ini mengandung pertanyaan seperti, what is your hobby?; where do you work?; what is your favorite food? ; where do you work?; what time do usually arrive at yor workplace? dan what do you think about this program?.

Kegiatan yang diadakan untuk karang taruna dilakukan sebanyak kurang lebih 10 kali pertemuan. Proses pengajaran pada karang taruna lebih ditekankan pada kemampuan mereka untuk membuat surat lamaran dalam Bahasa Inggris, berbicara dan kemampuan untuk membaca teks-teks yang berkaitan dengan penyelamatan alam. Dalam hal speaking, metode yang digunakan adalah cooperative learning. Metode pembelajaaran ini merupakan salah satu strategi pembelajaran yang menekankan pada keaktifan dari peserta di dalam proses pembelajaran (Susanti \& Rukiati, 2017).

Metode cooperative learning dipilih karena metode ini dianggap sangat sesuai dengan pelatihan ini. Di dalam metode ini, peserta akan mampu untuk bekerjasama untuk menjawab pertanyaan yang akan diberikan. Ditambah lagi, para peserta dengan interaksi yang baik mampu untuk bekerjasama dan membangun kelompok belajar bersama pula (Syafri, 2007). Dengan adanya interaksi seperti ini, tentunya para peserta akan lebih bersemangat lagi belajar.

Dalam hal pengajaran reading (membaca) dan writing (menulis), metode ini diterapkan juga. Kegiatan membaca bukanlah kegiatan yang pasif, kegiatan ini harus diikuti dengan aktif. Pembaca diharuskan untuk merekonstruksi makna yang ingin disampaikan. Teks yang diberikan berupa buku bergambar yang memuat tata cara penanaman pohon dan pencegahan banjir. Oleh karena itu, sebagian dari para pemuda kemudian melakukan gerakan untuk penyegaran berupa penanaman pohon.

Pada pertemuan awal dengan para peserta, dilakukan tes wawancara sebagai bagian dari pre-test untuk mengetahui kemampuan peserta. Tes wawancara pertama diadakan oleh tim pengabdi. Setelah itu para peserta diberikan daftar pertanyaan dan mereka melakukan wawancara diantara peserta. Hal ini dilakukan agar peserta yang hasil tesnya cukup baik dapat dipasangkan dengan peserta yang hasil tesnya agak kurang. Hal ini dilakukan sesuai dengan prinsip cooperative learning (Syafri, 2007). Tes ini dilakukan secara acak untuk memberikan peserta kesempatan berimprovisasi. Seperti yang dikemukakan sebelumnya, hanya pada kelompok karang taruna sajalah yang diberikan pre-test dan post-test. Hasil dari pre-test peserta disajikan dalam tabel 1 . 
Tabel 1. Hasil Pre-TestPeserta Karang Taruna Peningkatan Kemampuan Bahasa Inggris

\begin{tabular}{clcccc}
\hline \multirow{2}{*}{ No } & \multicolumn{1}{c}{ Nama } & \multicolumn{3}{c}{ Hasil Pre-Test } & \multirow{2}{*}{ Rata-rata } \\
\cline { 3 - 5 } & & Matter & Manner & Method & \\
\hline 1. & Muh. Asrul & 70 & 70 & 70 & 70 \\
2. & Arifuddin & 70 & 71 & 69 & 70 \\
3. & Muhammad Yamin & 69 & 69 & 69 & 69 \\
4. & Ilham & 71 & 65 & 75 & 70.3 \\
5. & Amir & 66 & 69 & 64 & 66.3 \\
6. & Rahmat Hidayat & 75 & 72 & 72 & 73.0 \\
7. & Zulham Nur & 71 & 70 & 69 & 70 \\
8. & Arifuddin Yaqim & 67 & 67 & 65 & 66.3 \\
9. & Khaeruddin & 71 & 68 & 66 & 68.3 \\
10. & Syukri & 65 & 64 & 64 & 64.3 \\
\hline
\end{tabular}

Keterangan: $80-100=$ Sangat Baik; $60-80=$ Baik; $40-60=$ Kurang; $00-40=$ Tidak Lulus

Hasil yang diperoleh dari kegiatan pre-test di kegiatan ini dapat dikategorikan Baik. Nilai rata-rata terendah yang diperoleh adalah 64.3 dan yang tertinggi adalah 73 . Hal ini dapat dimaknai bahwa kemampuan dasar Bahasa Inggris yang ada pada kelompok Karang Taruna ini bukan tidak mungkin ditingkatkan menjadi sangat baik. Hal ini dikarenakan pada saat pre-test ini tidak ada peserta yang mendapatkan nilai kurang.

Tidak terlupa juga, kegiatan ini memiliki tahap evaluasi. Pada tahap evaluasi ini diadakan latihan atau semacam ujian dengan tujuan untuk melihat sejauh mana materi yang siswa mampu serap. Evaluasi berupa latihan yang berupa percakapan maupun tertulis. Adanya praktek berupa percakapan juga diterapakan dalam hal evaluasi. Kegiatan PKM ini akan menggunakan beberapa metode evaluasi yaitu; evaluasi secara berproses. Dalam evaluasi ini tim pelaksana melakukan proses dalam hal pelatihan peningkatan kemampuan Bahasa Inggris. Pada proses ini, tim pelaksana akan melakukan identifikasi kendala yang muncul selama kegiatan. Kendala tersebut meliputi, materi ajar, proses pelatihan dan mengenai peserta.

Untuk hal materi ajar, materi yang digunakan adalah materi yang telah disusun oleh tim pengabdi yang mengacu pada buku English for Everyone: Level 1 yang ditulis oleh DK. Buku ini dipilih karena cukup lengkap dan mengandung materi-materi yang mewakili subjek pelajaran selama kegiatan. Sedangkan untuk proses pelatihan dilihat dari efisiensi waktu dan hasil belajar dari peserta selama proses pengabdian ini. Terakhir, yang dimaksud dengan peserta adalah keseriusan dan kehadiran peserta dalam mengikuti proses pelatihan.

Selanjutnya, untuk evaluasi kedua yaitu evaluasi akhir. Evaluasi akhir adalah evaluasi yang dilakukan diakhir kegiatan pengabdian ini. Evaluasi ini mencakup ketercapaian tujuan kegiatan, tingkat penguasaan materi oleh peserta dan pandangan mengenai keberlanjutan kegiatan pelatihan ini. Pada evaluasi akhir menunjukkan bahwa, peserta mampu menggunakan daily conversation dengan cukup baik. Tim pengabdi dapat melihat ini perkembangan ini melalui wawancara akhir sebagai bagian dari post test yang dilakukan. Hasil dari post-test setelah proses kegiatan pengabdian disajikan dalam tabel 2 . 
Tabel 2. Hasil Post-Test Peserta Karang Taruna Peningkatan Kemampuan Bahasa Inggris

\begin{tabular}{clcccc}
\hline \multirow{2}{*}{ No } & \multicolumn{1}{c}{ Nama } & \multicolumn{3}{c}{ Hasil Pre-Test } & \multirow{2}{*}{ Rata-rata } \\
\cline { 3 - 5 } & & Matter & Manner & Method & \\
\hline 1. & Muh. Asrul & 74 & 73 & 72 & 73 \\
2. & Arifuddin & 74 & 72 & 72 & 72.7 \\
3. & Muhammad Yamin & 72 & 73 & 72 & 72.3 \\
4. & Ilham & 74 & 72 & 73 & 73 \\
5. & Amir & 71 & 70 & 70 & 70.3 \\
6. & Rahmat Hidayat & 77 & 75 & 75 & 75 \\
7. & Zulham Nur & 72 & 72 & 72 & 72 \\
8. & Arifuddin Yaqim & 70 & 70 & 75 & 71.6 \\
9. & Khaeruddin & 72 & 70 & 72 & 71.3 \\
10. & Syukri & 70 & 72 & 70 & 70.6 \\
\hline
\end{tabular}

Keterangan: $80-100=$ Sangat Baik; $60-80=$ Baik; $40-60=$ Kurang; $00-40=$ Tidak Lulus

Berdasarkan hasil post-test yang telah diperoleh dapat ditarik kesimpulan bahwasanya masih berada pada kategori Baik. Nilai rata-rata terendah pada post-test ini adalah 70.3 sedangkan yang tertinggi adalah 75 . Hasil ini jika dibandingkan pada pre-test mengalami kemajuan yang bisa dikatakan cukup signifikan terlihat pada kenaikan sebanyak $\mathbf{3} \%$. Angka ini menunjukkan bahwa ada kemajuan dari sebelum dan setelah proses pembelajaran. Nilai tersebut adalah, 64.3 (satu orang) untuk nilai terendah dan 73 (satu orang) untuk nilai tertinggi.
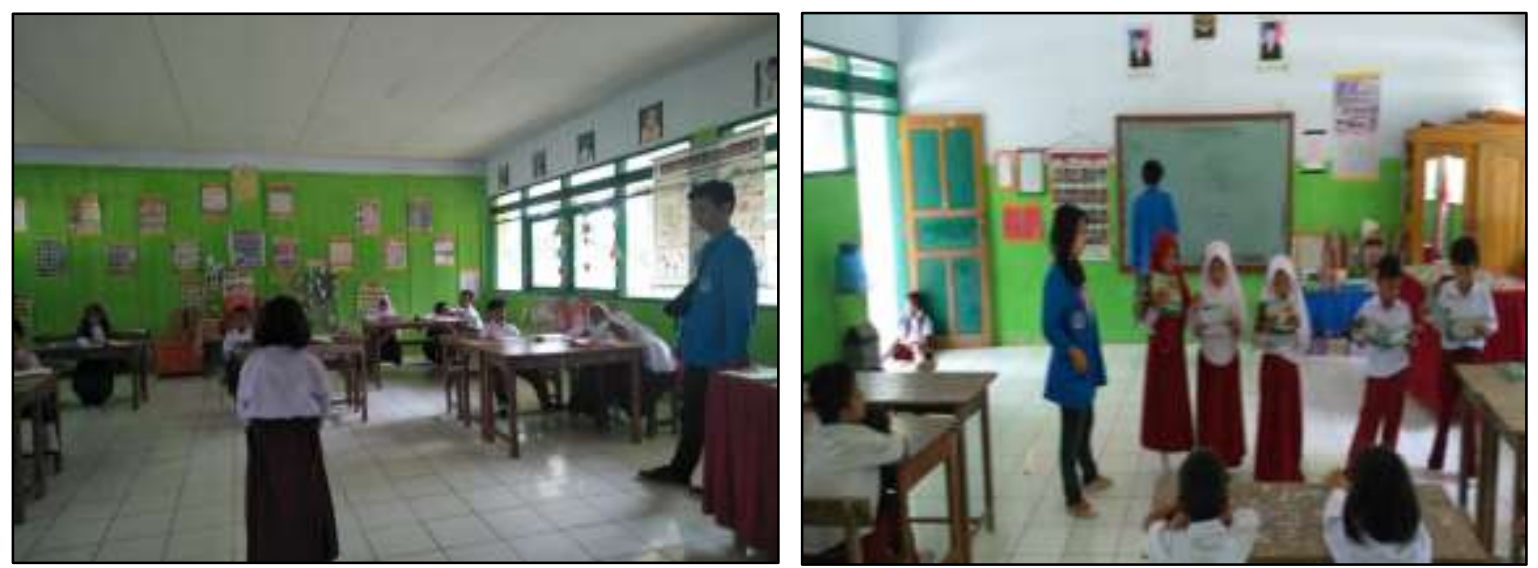

Gambar 2. Tahap Evaluasi

Hal yang penting dalam pelaksanaan kegiatan ini adalah beberapa capaian hasil kegiatan yang di terapkan dalam masyarakat. Soft skill dalam hal kemampuan berbahasa asing, salah satunya adalah Bahasa Inggris diharapkan dapat meningkatkan kemampuan bagi anak-anak dan pemuda di desa ini. Hal ini dikarenakan penguasaan Bahasa merupakan salah satu hal yang mampu meningkatkan daya saing masyarakat di era teknologi (Tamrin \& Ali, 2019). Hasil kegiatan yang dicapai pada kegiatan PKM ini adalah sebagai berikut: 1) Pemuda dan anak-anak yang mampu menggunakan Bahasa Inggris, 2) Buku Cerita Rakyat Lingkungan/Alam sekitar yang berbahasa Inggris, dan 3) Sumber Daya Manusia yang terampil. Pelatihan seperti ini juga 
memberikan hasil berupa kemampuan dan keinginan untuk belajar lebih dari peserta. Hal ini sejalan dengan yang mengatakan bahwa peserta bertambah minat dan untuk mempelajari Bahasa Inggris yang dapat dilihat dari keaktifan peserta dalam memberikan pertanyaan. Suasana yang asri juga mendukung terciptanya proses penyampaian materi dengan lebih baik.

\section{Kesimpulan}

Berdasarkan pembahasan yang telah disampaikan sebelumnya maka dapat ditarik kesimpulan bahwa kegiatan peningkatan minat belajar Bahasa Inggris di wilayah ini sangat bermanfaat dan menarik minat dari para peserta. Karena anak-anak dan para pemuda sangat berpeluang dan mampu menyerap pelajaran yang telah diberikan dengan baik. Hal ini dapat terlihat dari antusiasme mereka dalam proses belajar dan terjadinya suatu kegiatan yang lebih berguna setelah adanya kegiatan pengabdian ini. Dalam kegiatan pengabdian ini teori yang diterapkan dapat memberikan hasil yang diharapkan. Hal ini dapat terlihat dari naiknya beberapa nilai skill beberapa peserta. Meskipun nilai tersebut tidak melonjak terlalu tinggi, namun ada beberapa peserta yang mengalami kenaikkan yang cukup signifikan. Materi yang diberikan kepada peserta, baik di tingkat Sekolah Dasar dan pemuda karang taruna, dianggap sudah sesuai. Hal ini didasarkan juga kepada hasil yang diperoleh peserta.

\section{Ucapan Terima Kasih}

Penulis dan tim pengabdian mengucapkan banyak terima kasih kepada Kementrian Riset, Teknologi dan Pendidikan Tinggi (Kemenristek DIKTI) yang telah meloloskan dan mendanai program PKM ini. Kegiatan ini dibiayai dengan anggaran DPRM Kemenristek DIKTI. Terima kasih kami sampaikan kepada LPPM Universitas Fajar yang senantiasa membantu terlaksananya kegiatan pengabdian ini.

\section{Referensi}

Dahniar, N., Nurmaya, A. L., \& Irsan. (2018). Pelatihan Kemampuan Berbicara Bahasa Inggris Dalam Percakapan Sehari-Hari Bagi Para Pemuda Di Kota Bau-Bau. Jurnal Ppm Membangun, 2(1), 63-73.

Handayani, S. (2016). Pentingnya Kemampuan Berbahasa Inggris Sebagai Dalam Menyongsong Asean. Ikatan Sarjana Pendidikan Indonesia (Ispi) Jawa Tengah, 3(1), 102-106. Retrieved From http://Ispijateng.Org/Wp-Content/Uploads/2016/05/Pentingnya-Kemampuan-BerbahasaInggris-Sebagai-Dalam-Menyongsong-Asean-Community-2015_Sri-Handayani.Pdf

Husein, A. M., \& Dewi, R. K. (2019). Peningkatan Kemampuan Pragmatis Penguasaan Bahasa Inggris Bagi Guru Di Mts. Jauharul Ulum Desa Locancang Panarukan Situbondo. Dedication: Jurnal Pengabdian Kepada Masyarakat, 3(1), 39-43.

Meylina, \& Sammir, H. (2019). Meningkatkan Kemampuan Belajar Bahasa Inggris Siswa Dengan Computer Based Learning. Jurnal Pengabdian Mitra Masyrakat (Jppm), 1(1), 1-7.

Muchtar, N., \& Ali, G. E. (2017). Penerapan Metode Intensive Reading Dan Extensive Reading Untuk Meningkatkan Kemampuan Membaca Teks Bahasa Inggris Mahasiswa. In Prosiding Seminar Hasil Penelitian (Snp2m) 2017 (Pp. 135-140).

St. Syamsudduha, S. S., \& Tekeng, N. Y. (2017). Penerapan Service Learning Dalam Pembelajaran Matakuliah Pedagogik Pada Kurikulum Pendidikan Calon Guru. Lentera Pendidikan: Jurnal IImu Tarbiyah Dan Keguruan, 20(1), 1-17. Https://Doi.Org/10.24252/Lp.2017v20n1a1

Sunardi. (2011). Internet Dalam Pembelajaran Bahasa Inggris (Vol. 2011). Prosiding Seminar Nasional Teknologi Informasi dan Komunikasi Terapan. 
Transformasi: Jurnal Pengabdian Masyarakat, Vol. 15, No. 2, Desember 2019: 61-72

Susanti, N., \& Rukiati, E. (2017). Pelatihan Bahasa Inggris Bagi Karang Taruna Di Desa Wisata Lombok Kulon Bondowoso. In Seminar Nasional Hasil Pengabdian Kepada Masyarakat 2017(Pp. 251-256).

Syafri, F. (2007). Metode Cooperative Learning Sebagai Salah Satu Alternatif Metode Pembelajaran Membaca Dalam Bahasa Inggris. Lembaran IImu Kependidikan, 36(2), 124-130.

Syahfutra, W., \& Niah, S. (2017). Menguasai Speaking Skill Bahasa Inggris Karyawan Di Sma Islam Terpadu Fadhilah. Jurnal Untuk Mu Negeri, 1(2), 49-54.

Tamrin, A. F., \& Ali, M. Y. (2019). Pkm Meningkatkan Pembelajaran Bahasa Inggris Bagi Tk-It Fajar Kompleks Mannuruki Berdasarkan Gambar Dan Peningkatan Softskil Remaja Masjid Nurul Ilham Di Kabupaten Maros. Journal Of Techno Entrepreneur Acta, 4(1). Retrieved From https://Journal.Unifa.Ac.Id/Index.Php/Tea/Article/View/75

Tamrin, A. F., \& Magfirah, S. (2019). Nature Theme Pictured Book Used In Teaching English For Elementary Students. Eralingua: Jurnal Pendidikan Bahasa Asing Dan Sastra, 3(1), 16-25. https://Doi.Org/10.26858/Eralingua.V3i1.8759

Wulandari, F. (2018). Pelatihan Keterampilan Bahasa Inggris Di Madrasah Aliyah Al Adabiy. Gervasi: Jurnal Pengabdian Kepada Masyarakat, 2(1), 104-111. 